\title{
Penilaian Risiko Kuantitatif Tubrukan Kapal dengan Platform : Studi Kasus Tubrukan Kapal dengan Wellhead Platform PHE-12
}

\author{
Faiz Farhansyah, Yeyes Mulyadi, dan AA.Bgs.Dinariyana
}

Jurusan Teknik Kelautan, Fakultas Teknologi Kelautan, Institut Teknologi Sepuluh Nopember (ITS)

Jl. Arief Rahman Hakim, Surabaya 60111 Indonesia

e-mail: yeyes@oe.its.ac.id; dinariyana@yahoo.com

\begin{abstract}
Abstrak - Pada tugas akhir ini dilakukan penilaian risiko tubrukan kapal pada platform, dengan mengambil studi kasus terhadap Platform PHE-12 milik PT. Pertamina Hulu Energi West Madura Offshore (PHE WMO) yang akan segera diinstalasi di blok Madura Barat, dan hanya berjarak 2,91 km dari arus pelayaran bebas. Penilaian risiko dilakukan dengan menghitung frekuensi kejadian dan konsekuensi kerusakan akibat tubrukan. Perhitungan frekuensi kejadian dilakukan dengan metode kuantitatif Computerized Risk Assessment of Shipping Hazard (CRASH) dengan memproyeksikan tubrukan passing vessel dengan platform PHE-12 melalui skenario head-on dan drifting. Sementara perhitungan konsekuensi dilakukan dengan mencari peluang kegagalan struktur (collapse) dari kekuatan ultimate struktur dan nilai plastisitas yang kemudian diranking pada ketentuan konsekuensi yang ditetapkan pada tabel konsekuensi IPC. Dari kedua perhitungan tersebut, didapat hasil tingkat frekuensi kejadian tubrukan dengan skenario headon adalah 0,021392 , sementara tubrukan dengan skenario drifting adalah 0,02999 . Sementara hasil pemetaan risiko dengan menilik nilai konsekuensi pada matriks menyatakan tubrukan kapal mendapat risiko tinggi. Didapatkan kesimpulan akhir bahwa penilaian risiko tubrukan kapal terhadap platform berada pada risiko tinggi. Langkah preventif yang diberikan adalah penambahan kekuatan struktur dengan fender, dan instalasi Automatic Radar Ploting Aid(ARPA), Radar Beacon (Racon), Vessel Traffic System (VTS) dan rekomendasi mitigasi grouting pada pile.
\end{abstract}

Kata Kunci- Tubrukan Kapal-Platform, Penilaian Risiko, Metode Kuantitatif CRASH, plastisitas, kegagalan struktur, collapse.

\section{PENDAHULUAN}

$\mathrm{P}$ ESATNYA pertumbuhan ekonomi di Indonesia saat ini, beriringan dengan konsumsi energi yang terus melonjak. Terbatasnya ruang fiskal untuk sektor energi terbarukan, membuat dependensi terhadap penggunaan energi fosil tidak terelakkan [3].Energi fosil berupa minyak dan gas bumi, menjadi salah satu bahan baku yang sangat dibutuhkan oleh masyarakat sebagai sumber penghidupan. Oleh karena itu, intensitas kegiatan eksplorasi dan eksploitasi minyak dan gas bumi di Indonesia menjadi sangat tinggi, dibuktikan dengan banyaknya pembangunan struktur lepas pantai (Offshore Platform) baru di Indonesia. Disisi lain, nawacita Presiden RI Joko Widodo untuk mengembalikan hegemoni Indonesia sebagai negara maritim, menumbuhkan kembali aktifitas kapal/pelayaran di Indonesia. Hal tersebut menimbulkan tendensi bahwa peluang terjadinya tubrukan antara kapal pada platform (Ship-Platform Collision) semakin besar, yang mana membuat masalah tubrukan tersebut memiliki urgensi tinggi dan menuntut kajian yang lebih komprehensif.

Salah satu daerah perairan Indonesia yang berpotensi terjadi tubrukan antara kapal dengan platform adalah perairan Madura. Ditemukannya banyak cadangan (reserves) hidrokarbon baru pada blok WMO daerah perairan Madura, membuat risiko tubrukan kapal pada platform di daerah ini semakin besar. Selain banyak pembangunan platform baru , perairan Madura merupakan salah satu perairan yang memiliki arus pelayaran terpadat dimana perairan tersebut dilewati kapal yang memiliki banyak rute lintas provinsi (kapal Surabaya-Makassar, Semarang-Samarinda, dan Surabaya- Kumai). Diestimasikan dalam hitungan per tahun, kapal yang melintas pada perairan ini berkisar 3.720 kapal. Fakta tersebut menunjukan bahwa proyeksi dan penilaian risiko perlu dilakukan, untuk memberikan rekomendasi mitigasi yang yang dapat digunakan instansi terkait untuk mencegah terjadinya tubrukan kapal dengan platform yang berdampak masif [1].

Dalam studi kasus tugas akhir kali ini, penulis mencoba melakukan penilaian risiko tubrukan kapal dengan salah satu platform milik PT. Pertamina Hulu Energi WMO (PHE WMO) yaitu PHE-12. PHE-12 merupakan Wellhead Platform berjenis unmmaned yang berada di blok WMO pada perairan Madura Barat. Lokasi PHE 12 Wellhead Platform berada di West Madura Offshore/Western, Offshore East Java, di koordinat 701678 m E dan 9271681 m N dari Bessel 1841. Dalam kajiannya, penulis melakukan penilaian risiko dengan menghitung proyeksi frekuensi tubrukan yang terjadi antara kapal dengan rute Makassar-Surabaya, Kumai-Surabaya dan Samarinda-Semarang yang hanya berjarak 2,91 km dari platform PHE-12 dengan metode penilaian risiko kuantitatif CRASH (Computerised Risk Assessment of Shipping Hazards). Selain itu penulis juga akan menganalisis konsekuensi yang terjadi pada platform, ketika tubrukan telah terjadi dengan bantuan software. Setelah perkiraan frekuensi dan konsekuensi telah dihitung, selanjutnya dilakukan evaluasi risiko untuk menentukan apakah risiko frekuensi dan konsuekensi dapat diterima atau tidak. Bila risiko berada dalam tahap tidak dapat diterima, penulis akan memberikan 
rekomendasi mitigasi yang mana kemudian dapat dijadikan pertimbangan oleh PT. PHE WMO untuk pengambilan keputusan

\section{URAIAN PENELITIAN}

Alur pengerjaan penelitian ini dilakukan dengan tahaptahap sebagai berikut :

\section{A. Studi Literatur}

Studi dan pengumpulan literatur sebagai bahan-bahan referensi dan sumber teori-teori yang berkaitan dan diperlukan dalam penyelesaian penelitian ini.

\section{B. Pengumupulan Data}

Data platform PHE-12, data traffic arus pelayaran dekat platform,dan data kapal digunakan dalam proses pengerjaan Tugas Akhir ini. Data tersebut didapat dari laporan Front End Engineering Design (FEED) PHE WMO, PT.PELNI, PT. Dharma Lautan Utama, dan situs vesseltracker (vesseltracker.com)

\section{Pemodelan dan Validasi Struktur}

Tahap yang dilakukan adalah memodelkan struktur sesuai dengan gambar teknik yang tersedia menggunakan bantuan Software. Setelah semua primary dan secondary member dimodelkan, maka akan ditentukan property member sesuai keterangan dari gambar teknik. Setelah itu memasukkan pembebanan yang bekerja pada struktur. Pembebanan berupa beban yang bekerja secara vertikal, lateral dan future load.

Setelah melakukan permodelan maka langkah selanjutnya yaitu Validasi data Struktur yang telah dimodelkan dengan data struktur sesuai report apakah sesuai dengan kondisi sebenarnya atau tidak dalam hal ini adalah berat struktur, apabila batas toleransi terlalu besar maka struktur harus dimodelkan ulang hingga batas toleransi kecil.

\section{Analisis Perhitungan Frekuensi}

Menghitung besarnya frekuensi kemungkinan terjadinya kejadian tubrukan kapal dengan platform PHE-12 dengan berbagai skenario yang mungkin terjadi menggunakan metode kuantitatif CRASH. Skenario model I dibuat ketika kapal yang rute pelayarannya dekat platform PHE-12 mengalami penyimpangan akibat kesalahan manusia dan kapal langsung menubruk platform, sementara skenario model II ketika kapal mengalami kerusakan propulsi dan menyebabkan drifting hingga menabrak platform . Dari kedua skenario tersebut didapatkan besarnya frekuensi per tahun tubrukan kapal dengan platform PHE-12.

\section{E. Analisis Perhitungan Konsekuensi}

Perhitungan konsekuensi dimulai dengan melakukan input beban tubrukan sesuai rumus energi kinetik ke dalam software, yang disesuaikan dengan skenario tubrukan. Setelah input dimasukan, software akan melakukan pemodelan tubrukan sesuai dengan data energi tubrukan yang telah diinput untuk mengetahui dampak tubrukan terhadap struktur, yang dapat dilihat dari rasio plastisitas pasca tubrukan. Pada tahap ini, penulis juga menggunakan metode pushover untuk mengetahui batas kecepatan kapal yang bisa diterima struktur untuk menyebabkan collapse, dan nilai RSR untuk menentukan skenario tubrukan yang akan diinvestigasi lebih lanjut apakah tubrukan arah 300 atau 600.

\section{F. Analisis Keandalan}

Setelah mendapatkan hasil rasio plastisitas dari energi tubrukan yang diinput pada perhitungan konsekuensi, selanjutnya adalah melakukan analisis keandalan sistem untuk menentukan probabilitas kegagalan struktur ketika ditabrak kapal. Dimulai dengan menentukan moda kegagalan struktur berdasarkan member yang mengalami plastisitas ketika terkena beban tubrukan. Dari moda kegagalan tersebut dilakukan analisis keandalan menggunakan simulasi Monte Carlo untuk mendapatkan keandalan sistem yang akan menjadi acuan untuk mendapatkanPoF (Probability of Failure) member struktur yang nantinya akan dimasukkan ke dalam matriks risiko. Selain itu dilakukan penilaian Consequence of Failure (CoF) berdasarkan matriks IPC.

\section{G. Penilaian Risiko}

Melakukan evaluasi dan penilaian risiko dengan memetakan frekuensi kejadian dan konsekuensi yang berasal dari output analisis keandalan yaitu probabilitas kegagalan sistem (struktur) ketika tertubruk. Penilaian dilakukan dengan memetakan frekuensi kejadian dan konsekuensi mengacu pada codes DNV-RP-G101 dan tabel konsekuensi IPCyang kemudian dilakukan pemeringkatan melalui matriks $5 \times 5$ yang dikustomisasi.

\section{H. Rekomendasi Mitigasi}

Rekomedasi Mitigasi dilakukan jika struktur memiliki tingkat risiko yang tinggi. Tingkat risiko struktur dilihat dari matriks risiko yang pada tugas akhir kali ini menggunakan matriks gabungan DNV-RP-G101 dan IPC. Mitigasi dilakukan untuk mengurangi tingkat resiko pada struktur

\section{HASIL DAN PEMBAHASAN}

\section{A. Pemodelan Struktur PHE 12 Wellhead Platform.}

Pemodelan PHE 12 Platform menggunakan perangkat lunak dengan menggunakan data pembebanan, lingkungan yang diatur pada drawingPHE-12 laporan FEED PT PHE WMO.

\section{B. Verifikasi Model}

Validasi struktur selalu dibutuhkan dalam melakukan permodelan. Validasi berguna untuk membuktikan bahwa permodelan yang dilakukan telah memberikan hasil yang kurang lebih dapat mewakili kondisi struktur sebenarnya. Dalam penelitian ini, pemodelan struktur dilakukan dengan menggunakan perangkat lunak berbasis metode elemen hingga. Validasi terhadap pemodelan dilakukan berdasarkan berat struktur. Berat struktur hasil pemodelan diperoleh dapat dilihat pada Tabel 3.1. 


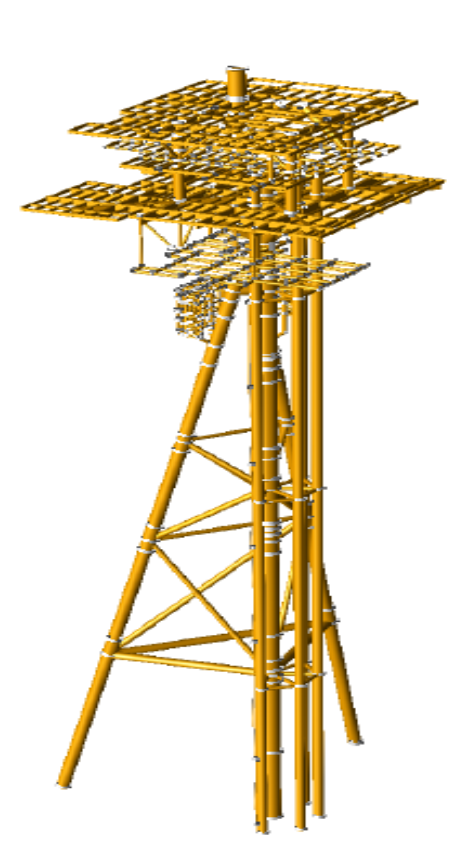

Gambar 3.1. Pemodelan PHE 12 Platform (Isometric View)

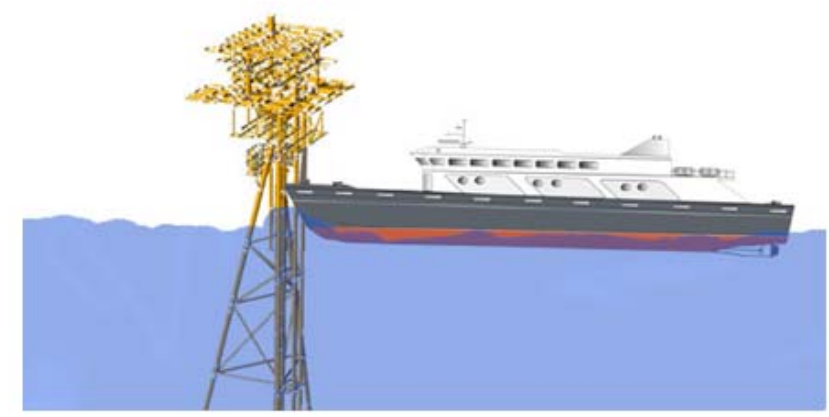

Gambar 3.2. Ilustrasi Skenario Tubrukan

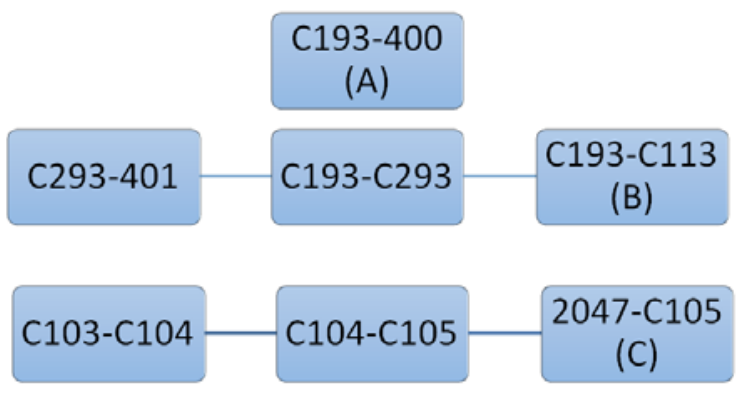

Gambar 3.3 RBD tubrukan arah $60^{\circ}$

\begin{tabular}{c|c|c|c|c|c|} 
& \multicolumn{5}{|c|}{ Consequences } \\
\hline Frequency & 1 & 2 & 3 & 4 & 5 \\
\hline 5 & & & & & \\
\hline 4 & & & & 60 & \\
\hline 3 & & & & & \\
\hline 2 & & & & & \\
\hline 1 & & & & & \\
\hline
\end{tabular}

Gambar 3.4 Matriks Risiko Tubrukan Arah 60

Tabel 3.1 Validasi Struktur PHE 12

\begin{tabular}{|c|c|c|c|}
\hline \multirow{2}{*}{ Platform } & \multicolumn{2}{|c|}{ Berat Struktur (Kips) } & \multirow{2}{*}{ Koreksi (\%) } \\
\cline { 2 - 3 } & Data & Permodelan & \\
\hline \multirow{2}{*}{ PHE 12 WP } & 1387,728 & 1353,1201 & 2,5 \\
\hline
\end{tabular}

Tabel 3.2 Perhitungan Frekuensi Tubrukan Head-On Collision

\begin{tabular}{lccccc}
\hline & & & & & \\
& $\mathrm{P}_{1}$ & $\mathrm{P}_{2}$ & $\mathrm{f}(\mathrm{A})$ & $\mathrm{D}$ & $\mathrm{F}_{\mathrm{d}}=\mathrm{Dx} \mathrm{f}(\mathrm{A})$ \\
\hline Platform PHE-12 & 0,9 & 0,9 & 0,0 & 39,80 & 0,013 \\
\hline
\end{tabular}

\begin{tabular}{ll}
\hline & PHE-12 \\
\hline Jumlah Kapal (N) & 3720 \\
$F_{d}$ & 0,013 \\
Failure Voyage (P1) & $0,51 \%$ \\
Human Factors (P2) & $74 \%$ \\
Failure Alerting (P3) & $12 \%$ \\
Frekuensi Tubrukan & 0,02139 \\
\hline
\end{tabular}

Tabel 3.3 Hasil Perhitungan Drifting Collision PERHITUNGAN 1

\begin{tabular}{|c|c|c|}
\hline & Drifting Collision & Box 1 \\
\hline$N$ & Totol traffic in the box & 3720 \\
\hline$L$ & Length of box (nm) & 9,1000 \\
\hline$S$ & Speed of drifting (knot) & 3 \\
\hline$P b 1$ & $\begin{array}{l}\text { Probability of breakdown per } \\
\text { hour in a radius of } 6 \mathrm{~mm}\end{array}$ & 0,00002 \\
\hline$P b I$ & $\begin{array}{l}\text { Probability of breakdown }= \\
\text { LS*PbI }\end{array}$ & $6,07 \mathrm{E}-05$ \\
\hline$P_{w}$ & $\begin{array}{l}\text { Probability of wind blowing } \\
\text { from box to object }\end{array}$ & 0,5 \\
\hline$D$ & Collision Diameter & 0,021 \\
\hline \multirow[t]{3}{*}{$B$} & $\begin{array}{l}\text { Box perpendicular to drift } \\
\text { direction }\end{array}$ & 0,0790 \\
\hline & $\begin{array}{l}\text { Pdrifting per box }= \\
N x P b x P w x D / B\end{array}$ & 0,029995 \\
\hline & Pdrifting Total $=$ & 0,029995443 \\
\hline
\end{tabular}

\begin{tabular}{|c|cc|c|c|}
\hline \multirow{2}{*}{$\begin{array}{c}\text { Kecepatan } \\
\text { Kapal }\end{array}$} & \multirow{3}{*}{$\begin{array}{c}\text { Arah } \\
\text { beban }\end{array}$} & \multicolumn{2}{|c|}{ RSR } & \\
\cline { 4 - 4 } & & RSR Min & RSR Max & SR \\
\hline \multirow{3}{*}{3 knot } & 30 & 6,222483 & 6,817615 & $\begin{array}{c}1,09564 \\
2\end{array}$ \\
\cline { 2 - 4 } & 60 & 2,155041 & 2,734933 & $\begin{array}{c}1,26908 \\
6\end{array}$ \\
\hline
\end{tabular}

Tabel 3.4 Output Base Shear dan RSR tubrukan drifting arah $30^{\circ}$ dan $60^{\circ}$ 
Tabel 3.5 Keandalan untuk Tubrukan Arah 60

\begin{tabular}{|c|c|c|c|c|c|c|c|c|}
\hline Member & GRP & P (kips) & My (kips- & 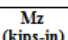 & $\mathrm{Pn}$ (kips) & $\overline{M p}_{\text {(kips- }}$ & K & POF \\
\hline C193-400 & SP1 & $-4088,6$ & 2235 & 31868 & 251,311 & 28644,7 & 0,49972 & 0,50028 \\
\hline C293-401 & SP1 & 619,68 & 391,86 & 35113 & 65,191 & 3999,8 & 0,50062 & 0,49938 \\
\hline 2047-C105 & $2 \mathrm{H}$ & 4,6194 & 319,6 & 1273 & 340,535 & 83,5 & 0,50174 & 0,49826 \\
\hline C193-C293 & SP5 & $-1266,6$ & 2163,3 & 17405 & 702,238 & 1952,8 & 0,47 & 0,53 \\
\hline C103-C104 & CND & 2386,7 & $-1906,04$ & 5293,7 & 2699,246 & 18220,1 & 0,41786 & 0,58214 \\
\hline C104-C105 & CND & $-892,99$ & 2598,3 & 5256 & 235,763 & 27952,5 & 0,60304 & 0,39696 \\
\hline C193-C113 & GD1 & 3576,3 & 1907,3 & 19960 & 1147,061 & 8720 & 0,64906 & 0,35094 \\
\hline
\end{tabular}

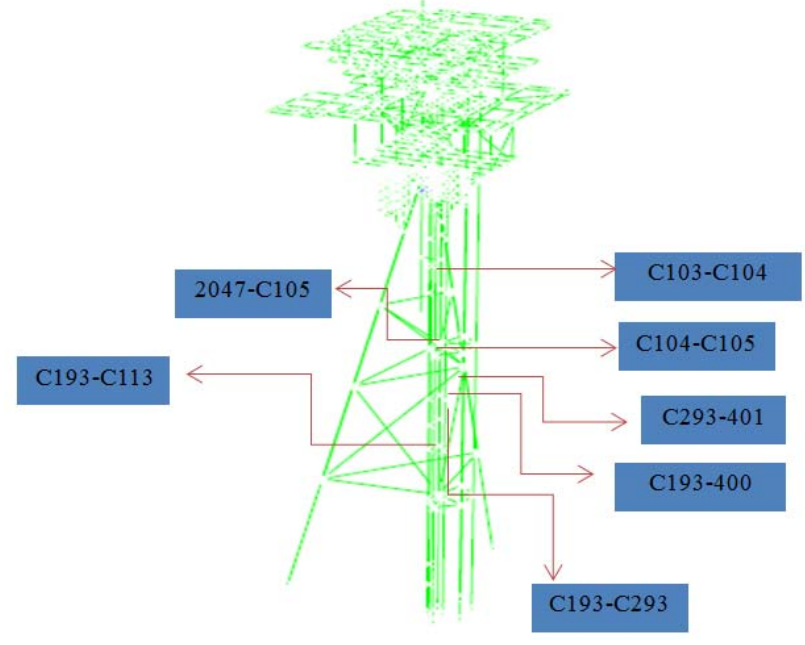

Tabel 3.6 Perhitungan Frekuensi

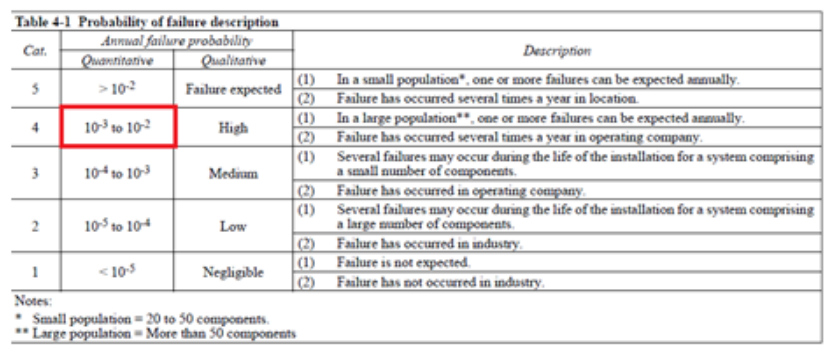

Tabel 3.7 Perhitungan Frekuensi

\begin{tabular}{|c|c|c|}
\hline Beban Arah & $\begin{array}{l}\text { Keandalan } \\
\text { Sistem (K) }\end{array}$ & $\begin{array}{c}\text { Peluang Kegagalan } \\
(1-\mathrm{K})\end{array}$ \\
\hline $60^{\circ}$ & 0,62884 & $0,37116(37 \%)$ \\
\hline
\end{tabular}

Tabel 3.8 Perhitungan Konsekuensi

\begin{tabular}{|l|l|}
\hline Probability Rank, $P$ & $\begin{array}{l}\text { Proposed Range of } \\
\text { Calculated } P_{\text {fail }}\end{array}$ \\
\hline 1 & $\mathrm{P}_{\text {fail }}<=0.1 \%$ \\
\hline 2 & $0.1 \%<\mathrm{P}_{\text {fail }}<=1 \%$ \\
\hline 3 & $1 \%<\mathrm{P}_{\text {fail }}<=10 \%$ \\
\hline \hline 4 & $10 \%<\mathrm{P}_{\text {fail }}<=50 \%$ \\
\hline \hline 5 & $\mathrm{P}_{\text {fail }}>50 \%$ \\
\hline
\end{tabular}

\section{Perhitungan Frekuensi Tubrukan Skenario I (Head-On Collision)}

Perhitungan frekuensi head-on collision dilakukan dengan menggunakan metode CRASH. Head-on collision adalah tubrukan dengan skenario dimana kapal yang melintasi alur pelayaran, menabrak platform dengan kecepatan tinggi. Hal tersebut diakibatkan penyimpangan kapal pada alur pelayaran yang dapat diakibatkan hal-hal yang dijabarkan pada Fault Tree Analysis pada langkah identifikasi bahaya sebelumnya. Berikut merupakan hasil perhitungan frekuensi head-on collision kapal yang diproyeksikan menabrak platform PHE-12.

Jika menilik dari hasil perhitungan diatas, maka perhitungan frekuensi kejadian head-on collision dengan metode CRASH memiliki nilai sebesar 0,021 yang dapat diklasifikasikan sebagai kelompok peluang risiko rendah (jarang terjadi), dikarenakan kalibrasi nilai pada perhitungan frekuensi ini adalah skala nol sampai dengan satu , dimana angka satu merujuk pada peluang risiko tertinggi (sering terjadi). Rendahnya nilai head-on collision dengan metode CRASH pada studi kasus PHE-12 ini bisa disimpulkan karena alur pelayaran yang sangat lebar yaitu sekitar enam kilometer membuat peluang terjadinya kapal menyimpang dari alur sangat kecil (mempengaruhi nilai variabel $\mathrm{Fd}$ ). Sementara pada perhitungan diatas, dapat dilihat bahwa nilai $f(A)$ yang merupakan kemungkinan kepadatan alur,memiliki nilai yang sangat kecil yaitu mendekati 0. Angka tersebut didapatkan setelah menghitung distribusi normal pada kepadatan arus pelayaran, yang mana kecilnya angka $f(A)$ juga mempengaruhi nilai akhir frekuensi head-on collision. Namun rendahnya nilai frekuensi tersebut belum tentu linier dengan konsekuensi yang terjadi apabila kapal menabrak platform PHE-12. Dikarenakan kapal penumpang yang memiliki dimensi sangat besar dan kecepatan yang cukup cepat, terjadinya tubrukan mungkin akan menyebabkan terjadinya keruntuhan atau collapse yang sangat merugikan instansi terkait. Untuk itu perlu dilakukan tinjauan komprehensif mengenai analisis konsekuensi tubrukan yang akan dilakukan pada sub bab selanjutnya pada analisis pushover.

\section{Perhitungan Frekuensi Tubrukan Skenario II ( Drifting Collision)}

Setelah perhitungan frekuensi head-on collision dilakukan, selanjutnya adalah perhitungan frekuensi skenario kedua yaitu tubrukan kapal pada platform dimana pada skenario ini, kapal mengalami kerusakan propulsi yang membuat kapal dapat menabrak platform dengan kecepatan yang rendah, diasumsikan 3 knot [5]. Walaupun pada skenario drifting ini, kapal menabrak dengan kecepatan rendah, implikasi yang dihasilkan bisa sangat membahayakan dan tidak menutup kemungkinan dapat menyebabkan platform collapse. Definisi dari Drifting collision sendiri adalah merupakan keadaan dimana kapal terseret oleh ombak ataupun adanya angin yang bertiup kearah suatu objek hingga kapal menubruk objek tersebut. Tubrukan ini pada umumnya diawali dengan adanya kegagalan engine dalam beroperasi sehingga engine 
shutdown.

\section{E. Analisis Konsekuensi}

Pada tahapan perhitungan konsekuensi kali ini, dimulai dengan menghitung energi kinetik hasil dari proyeksi tubrukan kapal dengan kecepatan 3 knot. Dari perhitungan energi kinetik dihasilkan nilai yang akan diinput pada software untuk dilakukan analisis konsekuensi tubrukan terhadap member pada struktur PHE-12. Berikut merupakan perhitungan energi kinetik

Energi Kinetik :

$$
\begin{aligned}
& \text { Energi Kinetik : } \\
& \begin{aligned}
\mathrm{E}= & 1 / 2 \mathrm{~m} \cdot \mathrm{v}^{2} \cdot \mathrm{k} \\
& =1 / 21.486 .500 \cdot(1,54)^{2} \cdot 1,1 \\
& =1.938 .960 \text { joule }=435,89 \mathrm{kips} \\
& =435,89 / 56,16=7,7 \mathrm{kips} / \mathrm{ft}
\end{aligned}
\end{aligned}
$$

Nilai 7,7 kips/ft tersebut yang akan diinput ke software untuk dilihat implikasi dari tubrukan apakah menyebabkan platform PHE-12 dapat collapse, dengan melihat rasio plastisitas member pasca tubrukan. Kemudian Arah yang memungkinkan terjadinya tubrukan drifting menurut penelitian CRASH sebelumnya adalah arah 300 dan 600 yang akan mengenai salah satu kaki member dari platform PHE-12. Untuk itu, dilakukan analisis pushover untuk menentukan nilai RSR dari kedua arah tersebut dan menentukan arah mana yang lebih memiliki urgensi tinggi untuk diinvestigasi lebih lanjut. Nilai RSR yang lebih rendah, menandakan arah tersebut dapat membuat struktur gagal lebih cepat. Untuk merepresentasikan gaya yang terjadi pada struktur, maka output analisis pushover yang digunakan adalah base shear. Base shear adalah gaya reaksi maksimum yang bekerja di permukaan tanah akibat beban lateral. Output base shear ini akan dijadikan parameter perhitungan RSR dan SR yang ditunjukkan pada tabel dan grafik 3.4. Bila menilik pada tabel diatas, dapat disimpulkan bahwa arah tubrukan 600 yang memiliki nilai RSR minimum yang lebih kecil, butuh diinvestigasi lebih lanjut pada sub bab selanjutnya, dibandingkan tubrukan arah 300 . Nilai RSR minimum yang lebih kecil merepresentasikan cadangan kekuatan struktur dalam menahan beban sangat sedikit dan membuat struktur lebih cepat collapse. Dapat dilihat bahwa tubrukan drifting dari arah 300 memiliki RSR minimum yaitu 6,222 yang artinya nilai tersebut masih dalam batas aman menurut code API-RP2 SIM yaitu tidak lebih dari 1,6. Sementara tubrukan drifting dari arah 600 memiliki RSR yang lebih kecil yaitu 2,155. Nilai tersebut menandakan bahwa struktur lebih cepat collapse ketika menerima tubrukan dari arah 600 dan diperlukan analisis lebih lanjut. Dari analisis sebelumnya didapat bahwa tubrukan drifting kecepatan 3 knot dari arah 600 memiliki urgensi tinggi untuk ditinjau lebih jauh. Dengan kapasitas cadangan struktur senilai 2,155 diperkirakan bahwa tubrukan drifting arah tersebut akan lebih membahayakan dan dapat membuat struktur PHE-12 lebih cepat collapse.
Selanjutnya, penulis mengilustrasikan skenario bagaimana tubrukan tersebut dapat terjadi.

\section{F. Analisis Keandalan}

Dalam melakukan analisis keandalan, tahapan pertama yang cukup penting untuk dilakukan adalah menentukan moda kegagalan. Moda kegagalan merupakan parameter dalam penentuan kesuksesan ataupun kegagalan suatu objek yang ditinjau, yang pada studi kasus tugas akhir ini adalah struktur Wellhead Platform PHE-12. Moda kegagalan yang digunakan dalam tugas akhir ini adalah persamaan kombinasi beban aksial dan bending moment yang merupakan faktor penting penyebab keruntuhan struktur seperti yang telah dijelaskan dalam bab sebelumnya.

Berikut merupakan moda kegagalan yang digunakan[2] :

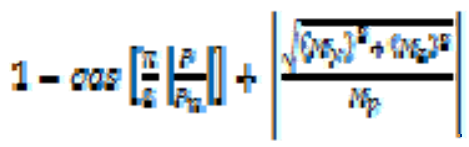

(AFI RF 2A 2007)

Dalam tugas akhir ini, objek yang menjadi tinjauan adalah member pada struktur Wellhead Platform PHE-12 yang mengalami plastisitas $100 \%$ akibat tubrukan kapal dari arah 600 . Member yang mengalami plastisitas 100\% akan dikatakan gagal apabila $\mathrm{MK}<0$ atau $\mathrm{MK}>1$ dan vice versa.

Analisis keandalan dilakukan dengan bantuan simulasi monte carlo untuk setiap member yang mengalami plastisitas 100 \% dengan menggunakan moda kegagalan yang telah ditentukan sebelumnya. Analisis keandalan ini dilakukan pada tubrukan drifting arah 600 sebagai arah yang paling cepat menyebabkan struktur mengalami keruntuhan. Selain itu analisis keandalan dapat digunakan untuk mengetahui kegagalan sistem secara keseluruhan, dengan menghitung terlebih dahulu keandalan sistem keseluruhan menggunakan reability block diagram. Hal tersebut dilakukan, karena tidak ada metode yang dapat mengetahui langsung PoF sistem dari resultan PoF member-member. Mekanisme pengerjaan analisis keandalan adalah dengan terlebih dahulu menentukan moda kegagalan. Setelah moda kegagalan ditentukan, berikutnya adalah menentukan variabel acak. Variabel acak ini berasal dari variabel-variabel persamaan moda kegagalan diatas yang memiliki ketidakpastian. Ketidakpastian ini yang digunakan untuk menggambarkan peluang kegagalan pada keadaan sebenarnya yang juga memiliki ketidakpastian yang tinggi. Berikut merupakan hasil dari simulasi monte carlo yang kemudian didapat nilai keandalan masing-masing member yang mengalami plastisitas pasca tubrukan. Kemudian untuk menghitung keandalan sistem akibat beban tubrukan arah 600 tersebut, maka ditentukan Reliability Block Diagram (RBD) terlebih dahulu.

Dari keterangan RBD, maka keandalan sistem dapat dihitung berdasarkan rumus dibawah ini:

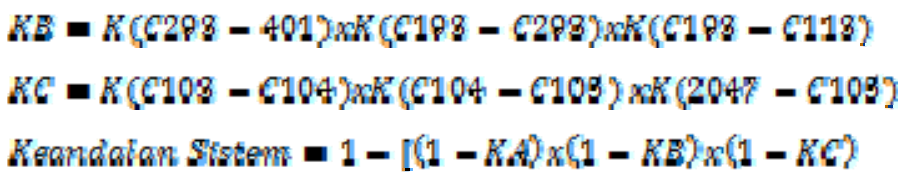

$$
=0,62884
$$




\section{G. Penilaian Risiko}

Penilaian risiko pada studi kasus tugas akhir ini dilakukan dengan mengacu pada codes DNV-RP-G101[4] untuk perhitungan frekuensi dan tabel konsekuensi IPC untuk perhitungan konsekuensi.. Pada tugas akhir ini, kasus kegagalan yang menjadi topik utama adalah merupakan kegagalan struktur secara keseluruhan yang diakibatkan member-member yang memiliki plastisitas $100 \%$ ketika terjadi tubrukan kapal. Untuk frekuensi kejadian, digunakan nilai dari perhitungan frekuensi drifting yang telah dihitung pada sub bab sebelumnya.Berikut merupakan frekuensi kejadian tubrukan kapal dengan platform PHE-12.

Dapat dilihat dari tabel diatas, frekuensi kejadian drifing collision masuk dalam kategori 4 atau high risk. Sementara itu, perhitungan konsekuensi yang menggunakan analisis keandalan dengan bantuan simulasi monte carlo, akan menghasilkan nilai probabilitas kegagalan (PoF) struktur PHE-12, yang mana kemudian akan diperingkatkan menggunakan tabel konsekuensi dari IPC. Hasil dari analisis keandalan yang telah dilakukan pada sub bab 4.3.6 menghasilkan nilai probabilitas kegagalan (collapse) struktur apabila menerima tubrukan drifting kapal arah 600 adalah bernilai 0,37116 atau $37 \%$. Berikut merupakan tabel dari peluang kegagalan yang didapatkan dari analisis keandalan, dan ranking konsekuensi yang diperingkatkan menggunakan tabel konsekuensi IPC. Dari tabel diatas dapat disimpulkan bahwa konsekuensi yang didapatkan dari nilai PoF pada analisis keandalan adalah 37\%, atau berada pada ranking 4 menurut rangking konsekuensi IPC. Selanjutnya, dilakukan pemetaan risiko pada matriks $5 \times 5$ yang telah dikustomisasi, dimana hasil dari

Pemeringkatan frekuensi dan konsekuensi dimasukan pada matriks risiko 5x5. Berikut merupakan hasil akhir dari penilaian risiko dapat dilihat pada Gambar 3.4.

Menilik pada hasil akhir penilaian risiko menggunakan matriks $5 \times 5$, dapat disimpulkan bahwa berdasarkan frekuensi kejadian dan konsekuensi yang direpresentasikan menggunakan nilai peluang kegagalan struktur akibat tubrukan kapal, risiko platform PHE-12 terhadap risiko tubrukan kapal berada pada risiko level 4 atau not acceptable (tidak dapat diterima). Hal itu dapat dilihat dari pemetaan matriks risiko diatas dimana frekuensi dan konsekuensi berada pada zona merah

\section{H. Rekomendasi Mitigasi}

Output dari penilaian risiko adalah memetakan tingkat risiko yang terjadi berada pada tingkat yang berbahaya atau tidak, disamping penilaian risiko tersebut harus diikuti dengan rekomendasi mitigasi. Menilik dari penilaian risiko menggunakan matriks risiko yang berada pada risiko tingkat tinggi, penulis menganjurkan agar instansi terkait melakukan mitigasi sebagai langkah preventif, yang dapat berupa penambahan performa desain pelindung struktur (fender), mewajibkan instalasi Automatic Radar Ploting Aid(ARPA), Radar Beacon (Racon) dan peggunaan Vessel Traffic System (VTS). Selain itu, langkah mitigasi yang perlu dilakukan apabila tubrukan telah terjadi adalah grouting pada pile.

\section{KESIMPULAN}

Dari analisis frekuensi menggunakan metode kuantitatif CRASH dan penilaian risiko Wellhead Platform PHE-12 terhadap tubrukan kapal yang telah dilakukan pada bab sebelumnya, dapat diambil kesimpulan sebagai berikut:

Dari perhitungan frekuensi yang dilakukan menggunakan metode kuantitatif Collision Risk Assessment of Shipping Hazard (CRASH) didapat nilai frekuensi kejadian tubrukan skenario drifting adalah 0,02999. Nilai tersebut menyimpulkan estimasi kejadian tubrukan kapal drifting menabrak platform adalah 30 tahun sekali.

Beban tubrukan arah 600 dapat menyebabkan konsekuensi kerusakan lokal pada struktur PHE-12. Dari perhitungan konsekuensi, didapat peluang kegagalan stuktur menjadi collapse akibat menerima beban tubrukan arah 600 adalah 0,37116 .

Hasil penilaian risiko dengan memetakan frekuensi kejadian dan konsekuensi kegagalan dari tubrukan arah 600 , pada matriks risiko $5 \times 5$ menurut DNV-RP-G101 adalah risiko tubrukan kapal terhadap platform PHE-12 berada pada level 4 atau not acceptable (tidak dapat diterima)

Instansi terkait perlu melakukan beberapa langkah preventif diantaranya adalah adalah ; meningkatkan performa desain pelindung struktur (fender), instalasi Automatic Radar Ploting Aid(ARPA), Radar Beacon (Racon), atau peggunaan Vessel Traffic System (VTS). Apabila tubrukan terjadi, maka tindakan mitigasi yang perlu dilakukan adalah dengan melakukan grouting pada pile.

\section{DAFTAR PUSTAKA}

[1] Armdahl, J and Johansen,A. 2001. High Energy Ship Collision With Jacket Legs. Proceedings of the Eleventh (2001) International Offshore and Polar Engineering Conference June 2001, Pages 373-377

[2] API RP 2A WSD. 2002. American Petroleum Institute. Washington D.C.

[3] Budiman A, et al.2014. Ten Ideas to Reshape Indonesia’s Energy Sector. McKinsey\&Company. Jakarta.

[4] DNV-RP-G101 ., 2010. Risk-Based Inspection OF OFFSHORE TOPSIDES STATIC MECHANICAL EQUIPMENT, NORWAY, OSLO.

[5] Kristiansen, Svein. 2005. Maritime Transportation: Safety Management and Risk Analysis. DNV Technica. 